\title{
O sistema-mundo capitalista e os novos alinhamentos geopolíticos no século XXI: uma visão prospectiva
}

The capitalist world-system and new geopolitical alignments in the 21st century: a prospective view

Carlos Eduardo Martins [l]

\section{Resumo}

Neste artigo, apontamos as principais características da conjuntura mundial contemporânea, suas tendências cíclicas e seculares, as configurações de poder dominantes, as forças antissistêmicas, os novos alinhamentos geopolíticos a que dão lugar e a bifurcação de poder que se desenha para os próximos anos. Desde 1994, vivenciamos uma fase de expansão do Kondratiev que se articula a dois movimentos descendentes de longa duração: a fase B do ciclo sistêmico estadunidense, marcada pela crise dessa hegemonia, iniciada em 1970; e a crise civilizatória do modo de produção capitalista, a partir do surgimento da revolução científico-técnica. Tal combinação traz características muito específicas para o ciclo longo de expansão que vivenciamos.

Palavras-chave: sistema-mundo; geopolítica; bifurcação; Estados Unidos; Brics.

\begin{abstract}
In this article, we point out the main characteristics of the contemporary world scenario, its cyclical and secular tendencies, the dominant power configurations, the anti-systemic forces, the new geopolitical alignments they give rise to, and the bifurcation of power that is drawn for the next years. Since 1994, we have been experiencing Kondratiev's phase of expansion, which is linked to two long-term descending movements: phase $B$ of the United States' systemic cycle, marked by the crisis of this hegemony, initiated in 1970, and the civilizational crisis of the capitalist mode of production, with the emergence of the scientifictechnical revolution. Such combination brings very specific characteristics to the long cycle of expansion that we have been experiencing.
\end{abstract}

Keywords: world-system; geopolitics; bifurcation; United States; BRICS. 
Em nossos trabalhos, temos nos dedicado a analisar a conjuntura mundial contemporânea a partir da perspectiva da longa duração, que interpreta o tempo concreto como a combinação simultânea de três temporalidades distintas que se articulam: a estrutural, cíclica e a do dia a dia. A singularidade de nosso tempo não pode ser compreendida sem analisarmos a articulação específica entre os tempos estrutural e cíclicos que se desenvolve hodiernamente. 0 tempo estrutural é cumulativo e irreversível, e as repetições cíclicas incidem sobre suas configurações concretas singulares, assumindo também formatos individualizados. Quanto maior a capacidade de as ciências sociais descreverem os processos estruturais e cíclicos em marcha e as formas concretas que assumem no tempo imediato, maior será a sua possibilidade de desenvolver um pensamento estratégico capaz de apontar as forças hegemônicas; as contra-hegemônicas; os arranjos de poder de longo, médio e curto prazo que resultam das guerras de posição e de movimento; e as bifurcações históricas que poderão dar lugar a uma ampla reconfiguração hierárquica do sistema mundo e das suas expressões de poder globais, regionais e nacionais.

Neste artigo, apontamos as principais características da conjuntura mundial contemporânea, suas tendências cíclicas e seculares, as configurações de poder dominantes, as forças antissistêmicas, os novos alinhamentos geopolíticos a que dão lugar e a bifurcação de poder que se desenha para os próximos anos. Desde 1994, vivenciamos uma fase de expansão do ciclo de Kondratiev que se articula a dois movimentos descendentes de longa duração: a fase B do ciclo sistêmico estadunidense, marcada pela crise dessa hegemonia, iniciada em 1970; e a crise civilizatória do modo de produção capitalista, a partir do surgimento da revolução científico-técnica, como nova estrutura de forças produtivas que impulsiona cada vez mais o desenvolvimento material da economia mundial. Tal combinação traz características muito específicas para o ciclo longo de expansão que vivenciamos: de um lado, a financeirização do capital, a crise de hegemonia do eixo atlantista da economia mundial e o declínio das potências marítimas, que tradicionalmente dirigiram a civilização capitalista, centradas, principalmente, no norte da Europa Ocidental e, atualmente, sob direção estadunidense; e, de outro, o deslocamento do dinamismo econômico para a China e para o Leste asiático, a ascensão dos regionalismos e dos hinterlands como novo possível fundamento geopolítico da economia mundial e da construção de um sistema-mundo multipolar.

Dividiremos este texto em 2 partes: na primeira, analisaremos as principais características do ciclo de Kondratiev vigente e os fundamentos da crise da hegemonia atlantista sobre a economia mundial; na segunda, analisaremos a ascensão da China e dos Brics e seus possíveis impactos geopolíticos.

\section{0 ciclo longo atual e a economia mundial}

Os ciclos ou ondas longas têm sido estudados por diversos autores desde os anos 1910 e 1920. Entre eles, destacam-se Jacob Van Gelderen, Nicolai Kondratiev, Joseph Schumpeter, Ernst Mandel, Christopher Freeman, Carlota Perez e Theotonio dos Santos. Por questões de espaço, não voltaremos a esse debate teórico que 
analisamos em profundidade em nosso livro, Globalização, dependência e neoliberalismo na América Latina (Martins, 2011b), mas utilizaremos aqui os principais instrumentos analíticos para a compreensão do funcionamento desses ciclos na economia mundial contemporânea.

Os ciclos longos, ou ciclos de Kondratiev autor russo que, por seus estudos, deu o nome a esses processos -, são uma forma de expressão razoavelmente sistemática do funcionamento da economia capitalista, concentrando-se nos países centrais desde o surgimento da revolução industrial no fim do século XVIII. Expressam a combinação e os desajustes entre paradigmas tecnológicos e organizacionais a estes relacionados. Rupturas tecnológicas radicais dão lugar a inovações primárias, secundárias e terciárias que confrontam estruturas e inércias organizacionais e abrem o espaço para inovações institucionais que se combinam com as tecnológicas para desenvolvê-las. Em linhas gerais, esses ciclos dividem-se em fases: a) de alto crescimento e b) de baixo crescimento e podem ser medidos pelas oscilações da taxa de crescimento do PIB per capita e da taxa de lucro. As fases de alto ou baixo crescimento influenciam os ciclos mais curtos, transmitindo-lhes seu ritmo, e sofrem, por sua vez, a influência de movimentos mais amplos. Os períodos de alta expansão e os de baixo crescimento dividem-se em subfases: os primeiros em retomada, prosperidade e maturidade; e os últimos em recessão, depressão e recuperação. A passagem para cada subfase é intermediada por uma pequena crise ou curta inflexão descendente.

Desde 1994, podemos situar a emergência de uma nova fase de expansão do ciclo longo na economia mundial, o que se observa pelos movimentos da taxa de crescimento do
PIB per capita mundial e da taxa de lucro que se elevam significativamente ante os patamares alcançados entre 1974-1993. Essa fase expansiva se inicia com a retomada entre 19941998, apresentando uma moderada inflexão no seu ritmo de crescimento em 2001, para retomar sua forte expansão na prosperidade que se estabelece entre 2002-2007. A crise de 2008-2009 é uma inflexão aguda que produz crescimento negativo durante um curto período de tempo, abrindo espaço para a subfase de maturidade que se inicia a partir de 2010. Esse período de crescimento longo, que provavelmente ingressa em sua última subfase e deverá se esgotar nesta década, apresenta características abaixo elencadas.

a) Menor intensidade de expansão em relação ao período 1950-1973, em razão de outros movimentos mais amplos de caráter descendente que atuam sobre ele.

b) Crescente deslocamento do dinamismo econômico para o Leste Asiático, em particular à China, com encadeamentos para as regiões que com ela se articulam.

c) Crise de hegemonia do eixo atlantista da economia mundial - e das periferias e semiperiferias a este articuladas - que avança com a sequência das subfases e de suas inflexões.

d) Lento e progressivo estabelecimento de uma bifurcação entre a hegemonia atlantista das potências marítimas e a ascensão de regionalismos e dos hinterlands.

A análise empírica baseada no PIB per capita mundial, sistematizado pela série formulada por Angus Maddison e seus seguidores, permite-nos visualizar os ciclos de Kondratiev desde meados dos anos 1870, quando começam efetivamente a se mundializar, com a difusão da grande indústria e com a organização 
de uma divisão internacional do trabalho a ela articulada, ainda que possam ser visualizados para os principais países industrializados, como a Grã Bretanha ou França, desde o fim do século XVIII, utilizando-se, como base estatística, o PIB per capita nacional. ${ }^{1}$ Se tomarmos o crescimento do PIB per capita como critério, podemos observar que, entre 1994-2010, a expansão anual atingiu 2,4\%, um salto drástico em relação à fase de estagnação relativa que a precedeu, quando este alcançou apenas $1,2 \%$ a.a. entre 1974-1993, mas ainda abaixo aos $2,9 \%$ do período de anos dourados da economia mundial, quando convergiram as fases expansivas do ciclo de Kondratiev e do ciclo sistêmico estadunidense da economia-mundo. Outro critério de mensuração é a taxa de lucro, cujos dados empíricos disponíveis são muito menos abrangentes e compreendem séries mais limitadas cronologicamente. Aqui utilizamos apenas as taxas de lucro dos Estados Unidos. Entretanto o peso desse país na economia mundial, como PIB ou como mercado mundial, e a profunda associação das oscilações da taxa de lucro estadunidense com as do crescimento econômico do PIB global nos permitem utilizar esse indicador como evidência probabilística desses ciclos. ${ }^{2}$

Além da taxa de lucro haver subido significativamente nos Estados Unidos a partir de 1994, diante do patamar que manteve, entre 1974-1993, a massa de lucros das corporações estadunidenses não financeiras oriundas do exterior se elevou dramaticamente, indicando o caráter internacional do movimento de elevação das taxas de lucro. Entre 1991-1994, a taxa de lucro subiu abruptamente nos Estados Unidos, em movimento similar, mas inverso ao de 1967-1970, quando caiu 52\%, saltando do patamar de 6,4\%, entre 1968-1993, para atingir a média de 9,1\% entre 1994-2013, nível próximo ao de 1959-1968, quando se nivelou em 10,3\% (Gráfico 1). A massa de lucros oriunda do exterior das corporações estadunidenses, por sua vez, elevou-se da faixa de 5\%-10\%, entre 1967-1970, para 15\%-20\%, entre 19942000 e 2000-2005, e 20\%-30\% entre 20082013 (Gráfico 2).

A dificuldade de muitos cientistas sociais em perceber o ciclo de expansão, para além de problemas analíticos, pode ser atribuída à mediocridade do desempenho da Europa Ocidental, dos Estados Unidos e do Japão nessa fase de expansão, em que o crescimento econômico é fortemente deslocado para o Leste Asiático, em particular para a China. Estados Unidos e Europa Ocidental apresentam crescimento do PIB per capita de 1,5\% a.a. entre 1994-2010, bem próximo à taxa de crescimento mundial na longa fase recessiva que precedeu ao período atual. Tal desempenho medíocre vem se aprofundando durante a trajetória dessa fase expansiva. De 1980-2000, os Estados Unidos cresceram bem acima da economia mundial, utilizando a elevação das taxas de juros e a sobrevalorização do dólar como instrumentos de reação contra a deterioração produtiva de sua hegemonia, bloqueando o dinamismo econômico mundial. Nesse período, o PIB per capita estadunidense expandiu-se em $2,2 \%$ contra $1,4 \%$ do PIB per capita mundial. Entretanto, os desequilíbrios financeiros e cambiais provocados e a elevação da competividade trazida pelo restabelecimento da fase expansiva evidenciaram, cada vez mais, os limites e as contradições da estratégia de financeirização do capital, obrigando os estados que a adotam a redefinir os seus termos, o que não os impede de serem 


\section{Gráfico 1 - Taxa de lucro nos Estados Unidos}

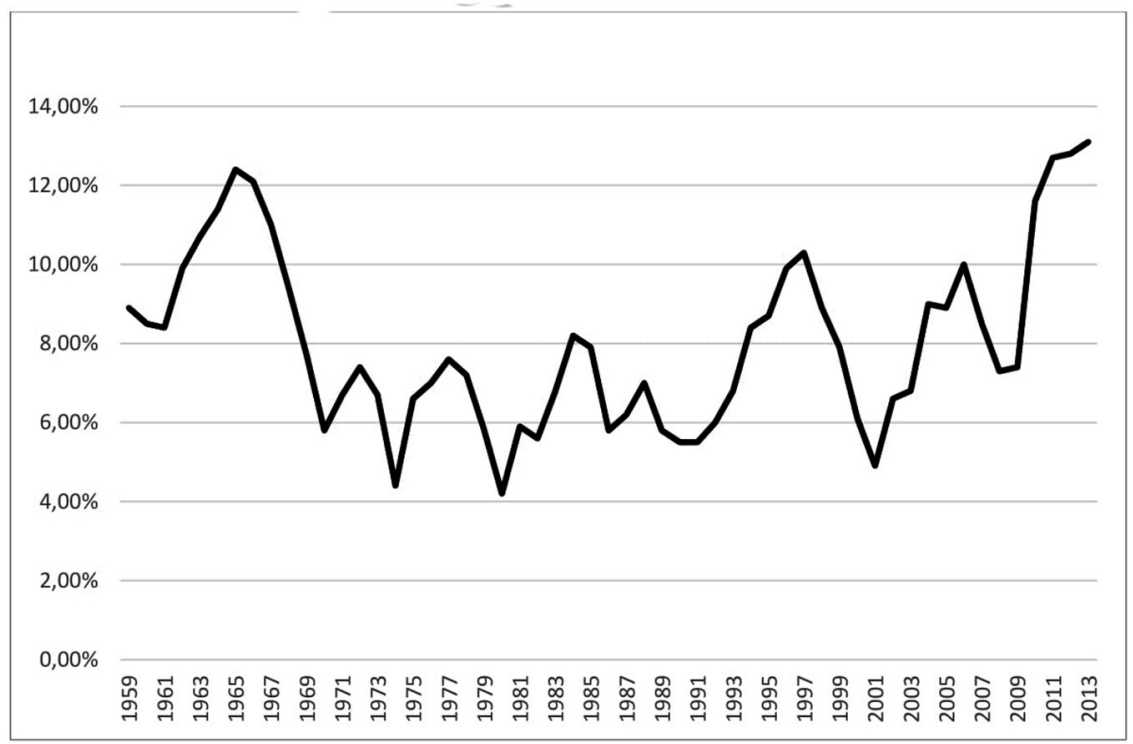

Fonte: elaborado pelo autor a partir do Council of Economic Advisers (2014).

Gráfico 2 - Massa de lucros das corporações estadunidenses vindas do exterior

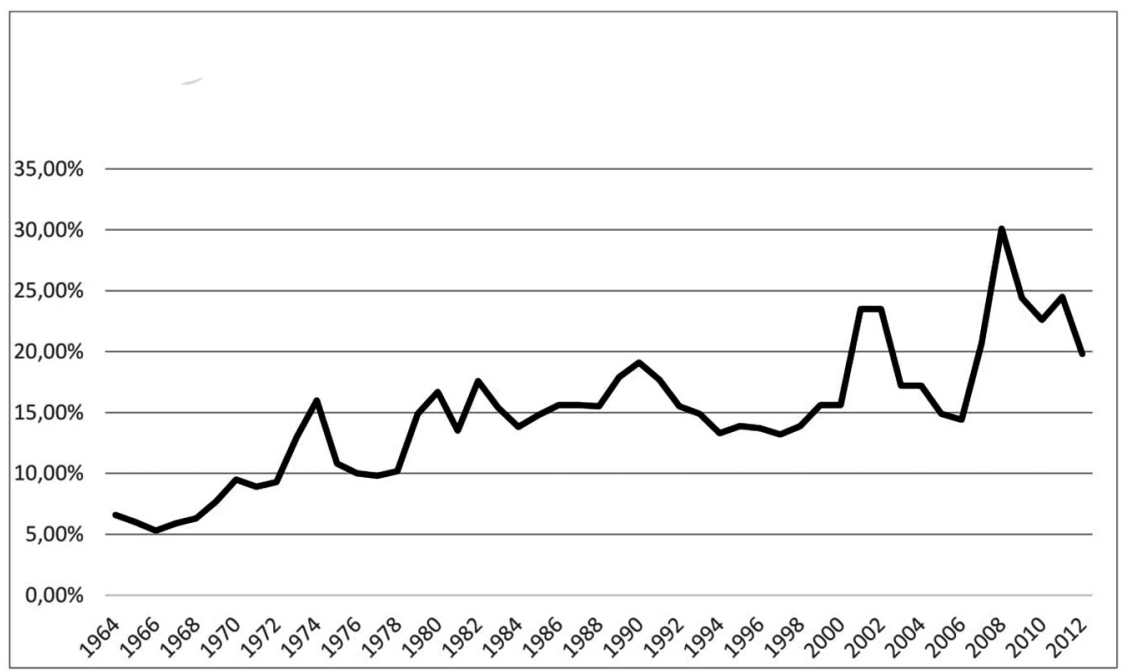

Fonte: elaborado pelo autor a partir do Council of Economic Advisers (2014). 
arrastados crescentemente ao parasitismo e à crise econômica, social, política e ideológica.

Se, entre 1994-2000, Estados Unidos e Europa Ocidental ainda suplantavam o crescimento do PIB per capita mundial, a partir de então a relação se inverte: o PIB mundial passa a crescer cada vez mais, quanto maior a mediocridade dos desempenhos estadunidense e europeu. Entre 2001-2010, o PIB per capita anual dos Estados Unidos e o da Europa Ocidental cresceram $0,6 \%$ e $0,8 \%$, respectivamente, enquanto o PIB per capita mundial o fez em 2,6\%, articulando-se cada vez mais à dinâmica chinesa (Bolt e Van Zaden, 2014). Se a economia mundial se recuperou da crise de 2008-2010 e manteve, entre 2011-2017, a sua trajetória de crescimento instituída entre 19942010, de 2,4\% ao ano, os Estados Unidos expandiram-se em apenas 1,3\% a.a. ${ }^{3}$ Essa frágil recuperação estadunidense é ainda inferior ao precário desempenho obtido por esse estado após a crise de 2000-2001, quando se expandiu em 1,6\% a.a. Em 1994, o PIB dos países avançados representou 58\% do PIB mundial; em 2007 representou 50\% e, em 2017, 41\%. ${ }^{4}$ Tais indicadores evidenciam que a trajetória do ciclo de Kondratiev vigente aprofunda, portanto, a crise do eixo atlantista que se inicia desde os anos 1970.

\section{A crise de hegemonia atlantista: fundamentos e dimensões}

A crise de hegemonia atlantista estabelece-se desde os anos 1970 e tem sua origem no esgotamento do pacto keynesiano que vinculou 0 aumento do gasto público ao estabelecimento do pleno emprego. Tal pacto se esgota com a ameaça estrutural que o pleno emprego passou a exercer sobre a taxa de lucro a partir da mundialização da revolução científico-técnica. Esta transforma o valor da força de trabalho no fundamento central da produtividade, ao estabelecer o conhecimento e a subjetividade como os principais elementos das forças produtivas. Inverte-se a lógica da revolução industrial na qual a produtividade era a expressão da desvalorização da força de trabalho ante a maquinaria, impulsionando o protagonismo da mais-valia relativa e da subsunção real do trabalho ao capital. ${ }^{5} \mathrm{~A}$ crise da subsunção real expressou-se nos movimentos de massa que se iniciaram de forma explosiva em 1968 e avançaram pelos anos 1970, unindo estudantes, trabalhadores e amplas minorias para confrontar a autocracia, o despotismo institucional da burocracia, a separação entre trabalhadores manuais e intelectuais, o colonialismo interno, os limites da democracia representativa, o imperialismo, a guerra e a destruição ecológica do planeta.

Essa ofensiva avança pela década de 1970, perdendo sua força explosiva, sendo confrontada pelo neoliberalismo, a partir da virada para os anos 1980, que substitui o keynesianismo, tornando-se um instrumento regulatório decisivo do capital para conter os novos movimentos sociais, refundar o Estado e criar as condições para o restabelecimento da taxa de lucro, impondo um mercado de trabalho com altos níveis de desemprego, fundado na queda dos preços da força de trabalho por debaixo de seu valor, estendendo aos grandes centros a superexploração do trabalho e destravando os obstáculos para a retomada dos processos de acumulação produtiva. 
A experiência neoliberal iniciou-se no Chile de Pinochet, estendendo-se para os Estados Unidos, Alemanha e Reino Unido e para o conjunto da Europa Ocidental no início dos anos 1980. Para eliminar o pleno emprego e estabelecer a superexploração do trabalho, o neoliberalismo impôs a financeirização do capital que deslocou parte da acumulação do setor produtivo ao financeiro, impulsionando a dívida pública e a competição pelo capital circulante, bem como a relocalização dos investimentos produtivos através da abertura comercial e liberalização dos fluxos de capital. A dívida pública passou a mover-se buscando a geração de capital fictício e não mais a produção de empregos e a elevação da produtividade. 0 neoliberalismo não significou a redução do Estado, mas a sua ampliação mediante o uso do monopólio da violência, direcionando os gastos públicos para sustentar os processos financeiros de acumulação e a competição armamentista, além de conter os gastos em bem estar-social. A relocalização dos investimentos, associada às novas tecnologias de produção para mercados mundiais, permitiu descentralizar parte da indústria, utilizando as vantagens competitivas da força de trabalho no mundo para redirecionar os fluxos de investimento produtivo. Ambos os processos reduziram a taxa de investimento nos países centrais, contribuindo a médio e longo prazos para o parasitismo e o desmonte da engrenagem de crescimento virtuoso do eixo atlantista.

Inicialmente a sobrevalorização do dólar significou acentuada elevação da riqueza da burguesia estadunidense, todavia a forte aceleração dos déficits comerciais, da dívida pública, e sua internacionalização entraram em contradição com os baixos estoques que apresentavam no início dos anos 1980, acumulando-se e colocando em xeque a diplomacia do dólar forte. Se, durante o ciclo de Kondratiev recessivo, a elevação das taxas de juros estadunidenses e a sobrevalorização do dólar impuseram-se sobre a economia mundial, sacrificando-a em função de sua dinâmica parasitária, ainda que sem impedir a formação de novos centros produtivos, a partir de 1994 é cada vez menor a capacidade de Estados Unidos e União Europeia imporem ao mundo a valorização de suas moedas e a sua política monetária. Entre 1979-1994, a elevação das taxas de juros estadunidenses aumentou dramaticamente os níveis de endividamento internacionais provocando o colapso dos projetos de modernização acelerada na periferia - baseados na dependência financeira externa, em particular na América Latina, Leste Europeu e África -, a forte redução das taxas de crescimento econômico mundiais e a drástica redução dos preços do petróleo. Nesse período, os Estados Unidos incrementaram de $417 \%$ para $458 \%$ seus níveis de renda per capita em relação à média da economia mundial, e o Norte da Europa somado à Itália o faz em menor escala, de $306 \%$ a $329 \% .{ }^{6}$ As contradições da diplomacia do dólar forte no âmbito do atlantismo foram resolvidas no início dos anos 1990, mediante o acentuado ajuste do iene e do marco, reduzindo o saldo comercial dessas economias com os Estados Unidos, mas também o seu dinamismo econômico, provocando o início da longa estagnação japonesa.

A crise de hegemonia do atlantismo iniciou-se por razões internas. Até 1979, não havia desafio significativo a sua competitividade por outras regiões do mundo. A hegemonia estadunidense permanecia sólida no interior do 
atlantismo e neutraliza a ofensiva econômica japonesa, impondo-Ihe o ajuste das políticas cambiais nos anos 1990. É a necessidade de prolongar a confrontação com sua classe trabalhadora, iniciada em fins dos anos 1960, mediante a conversão da superexploração do trabalho em uma política estrutural dos centros atlantistas, para além das inflexões cíclicas, que impulsionará essa crise. Sua implementação manteve os principais fundamentos da financeirização em período de crescimento longo da economia mundial e acelerou a relocalização dos investimentos produtivos. Tal ponto converge com as análises de Arrighi e Silver (2001) que apontam que na atual crise de hegemonia as contradições intraestatais seriam determinantes em relação às interestatais, diferentemente do período precedente no longo século britânico. ${ }^{7}$ Entre 1994-2010, a renda per capita dos Estados Unidos caiu de $458 \%$ para $390 \%$ da economia mundial e no Norte da Europa, incluída a Itália, de 329\% para 278\%. Nesse período, a China - que havia aproveitado a drástica elevação do iene, entre 1991-1994, para fazer o movimento oposto, desvalorizando fortemente sua moeda, atrelando-a ao dólar, e levando ao fracasso a gestão trilateral das contradições da financeirização estaduniden$\mathrm{se}^{8}$ - elevou sua participação no PIB mundial de $5,1 \%$, em 1979 , para $8,2 \%$, em 1991; $10 \%$, em 1994; e 17\%, em 2010. ${ }^{9}$

A crise de hegemonia do atlantismo apresenta diversas dimensões que se aprofundam nesse ciclo longo: a financeirização da economia, a queda das taxas de investimento, o aumento da dívida pública, o deslocamento para o exterior dos investimentos produtivos, a perda de competitividade internacional, a perda da autonomia da política monetária, o alto nível de desemprego, a contenção ou redução dos salários reais, o aumento da desigualdade, 0 aumento das assimetrias regionais e a substituição do liberalismo pelo neoliberalismo, gerando a crise do bipartidarismo. Vejamos esses aspectos em detalhe.

A financeirização da economia atlantista apresenta dois estágios: o primeiro impulsionado pelo aumento das taxas de juros, estimuladas pelo Federal Reserve Board (FED), o sistema de bancos centrais dos Estados Unidos, para a disputa do capital circulante, que se expressa num aumento drástico da dívida pública. Esse estágio predomina durante a fase recessiva do ciclo de Kondratiev, quando as taxas de juros reais são significativamente superiores às taxas de crescimento do PIB e implicam um peso significativo e crescente dos juros no orçamento público. Cria-se uma regulação da economia que eleva significativamente o gasto público em relação ao período keynesiano clássico, mas direciona-o, em grande parte, para a valorização do capital fictício. No segundo período, iniciado a partir da fase expansiva do ciclo de Kondratiev, as taxas de juros reais caem abaixo das taxas de expansão do PIB, mas a dívida pública e os gastos públicos permanecem crescendo a partir da intervenção do Estado no mercado privado de títulos financeiros, garantindo a liquidez de ativos podres quando este colapsa. A financeirização implica, ainda, uma queda significativa na taxa de investimento dos centros atlantistas que se associa a um duplo fenômeno que se desenvolve na formação dos lucros de suas corporações multinacionais: parcelas crescentes da massa de lucros originam-se no setor financeiro e no exterior - oriundas, nesse caso, dos investimentos de filiais dessas 
corporações. A perda de competitividade das economias atlantistas faz-se evidente na redução das taxas de crescimento econômico, na diminuição da parcela do PIB ou do comércio mundiais que representam - atualmente infladas pela sobrevalorização de suas moedas -, no crescimento de seus déficits comerciais, na internacionalização de suas dívidas públicas e na vulnerabilidade de seus balanços de pagamentos. 0 alto nível de endividamento público e a vulnerabilidade de seus balanços de pagamentos lhes vão retirando crescentemente a autonomia de suas políticas monetárias e cambiais pelos efeitos explosivos que podem exercer sobre o gasto público e o equilíbrio macroeconômico. Esses processos desenvolvem-se em maior ou menor grau entre os países atlantistas, apresentando-se, nos Estados Unidos, sua principal potência, com maior intensidade e nitidez. Na União Europeia, a Alemanha utiliza a contenção dos salários internos como um dos pilares da sua competividade, auferindo um expressivo saldo comercial com os países da zona do euro - 0 que contribui decisivamente para aprofundar as suas assimetrias internas e as desigualdades sociais e regionais - e com os Estados Unidos e o Reino Unido - países que mantêm suas moedas sobrevalorizadas - sem evitar, todavia, a queda de sua participação relativa no comércio mundial.

Os Gráficos 3 e 4 mostram o significativo aumento dos gastos públicos e da dívida pública nos Estados Unidos, na zona do euro, e de países da Organização para a Cooperação e Desenvolvimento Econômico (OCDE). Esta se elevou drasticamente na década de 1980, em função do incremento dos juros e de seu

\section{Gráfico 3 - Gastos públicos/PIB (\%)}

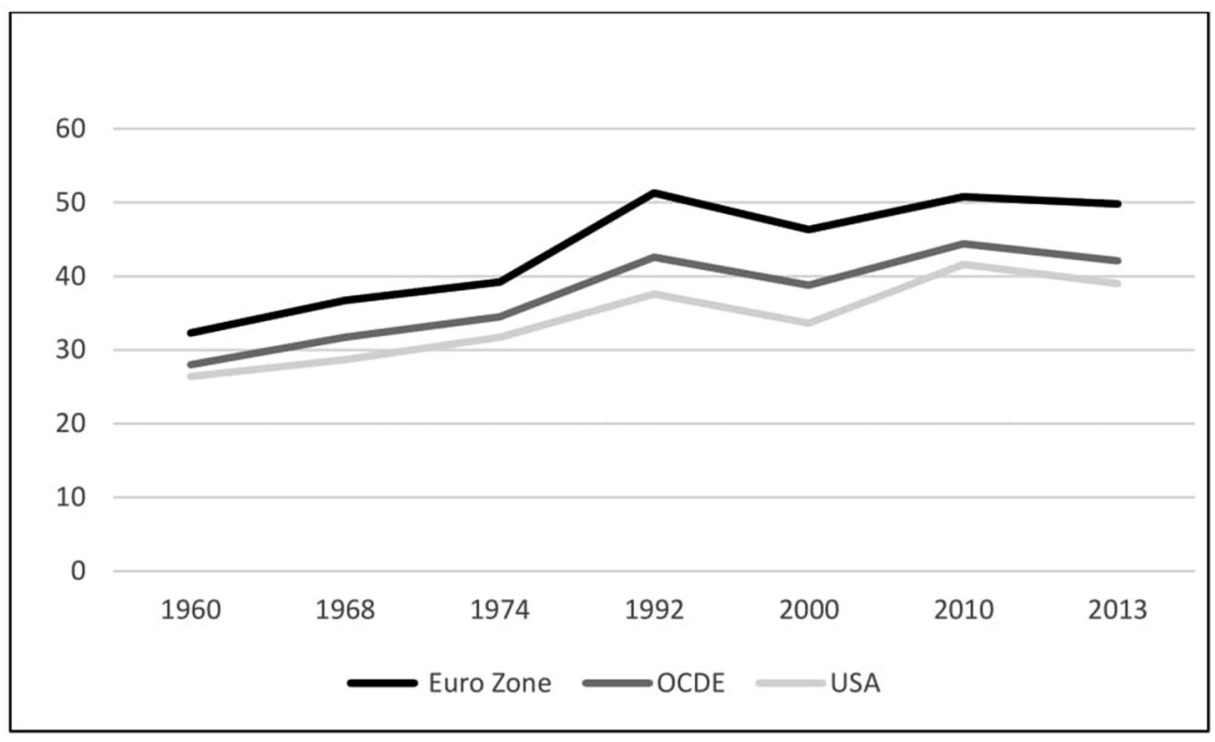

Fonte: elaborado pelo autor a partir de OECD (1998), (2001), (2010) e do Council of Economic Advisers (2014). 


\section{Gráfico 4 - Dívida bruta do governo/PIB}

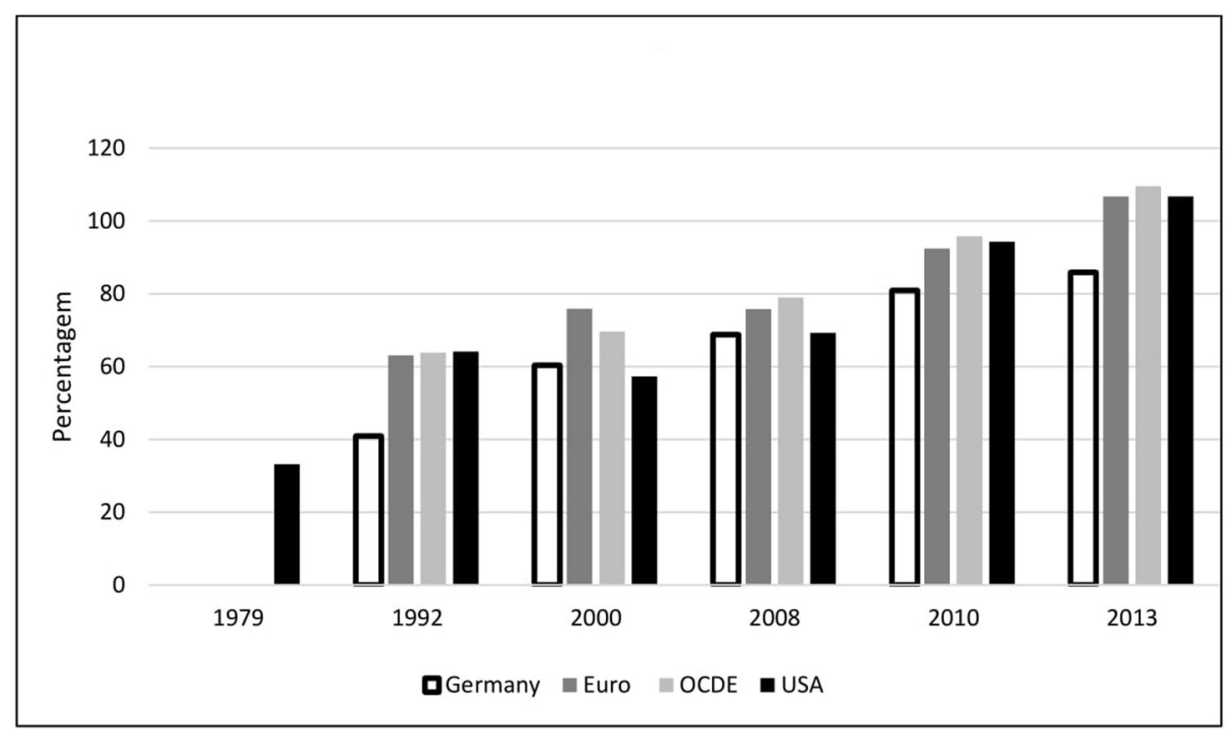

Fonte: elaborado pelo autor a partir de Economic Outlook 2014.1 e do Council of Economic Advisers (2014).

peso no orçamento público e, posteriormente, a partir da crise de 2008, em função da compra, por parte do Estado, de títulos podres, sustentando expectativas de lucros extraordinários sem liquidez. Entre 2008-2014/3, nos Estados Unidos, o governo federal comprou US\$4,2 trilhões em dívidas hipotecárias no mercado privado, e as instituições financeiras privadas, por sua vez, desfizeram-se de US $\$ 4,5$ trilhões que tinham sob controle, 0 que indica 0 alto nível de rentabilidade dessas operações. ${ }^{10} \mathrm{Na} z o n a$ do euro, a ajuda dos governos europeus aos bancos alcançou $\notin 4,5$ trilhões, aproximadamente $36,7 \%$ do PIB europeu, dos quais foram usados $\notin 1,6$ trilhões entre 2008-2010. Entre dezembro de 2011 e fevereiro de 2012, dois novos programas de refinanciamento de longo prazo emprestaram $\notin 1,1$ trilhões aos bancos europeus, com liquidez de $\notin 520$ bilhões. Desenvolve-se um capitalismo monopolista de Estado que sustenta lucros extraordinários fortemente desvinculados do progresso tecnológico e dos investimentos produtivos nos países centrais.

0 processo de financeirização vincula-se à queda das taxas de investimento nos países centrais que pode ser estimada por um conjunto de indicadores: a queda nas taxas de investimento nos Estados Unidos (Gráfico 5), a queda nas taxas de poupança na Europa Ocidental e Japão (Gráfico 6), o aumento dos lucros de origem financeiros (Gráfico 7) e dos lucros obtidos no exterior na massa geral de lucros das corporações estadunidenses. 0 aumento do 
Gráfico 5 - Taxa de investimento EUA/PIB (Percentual)

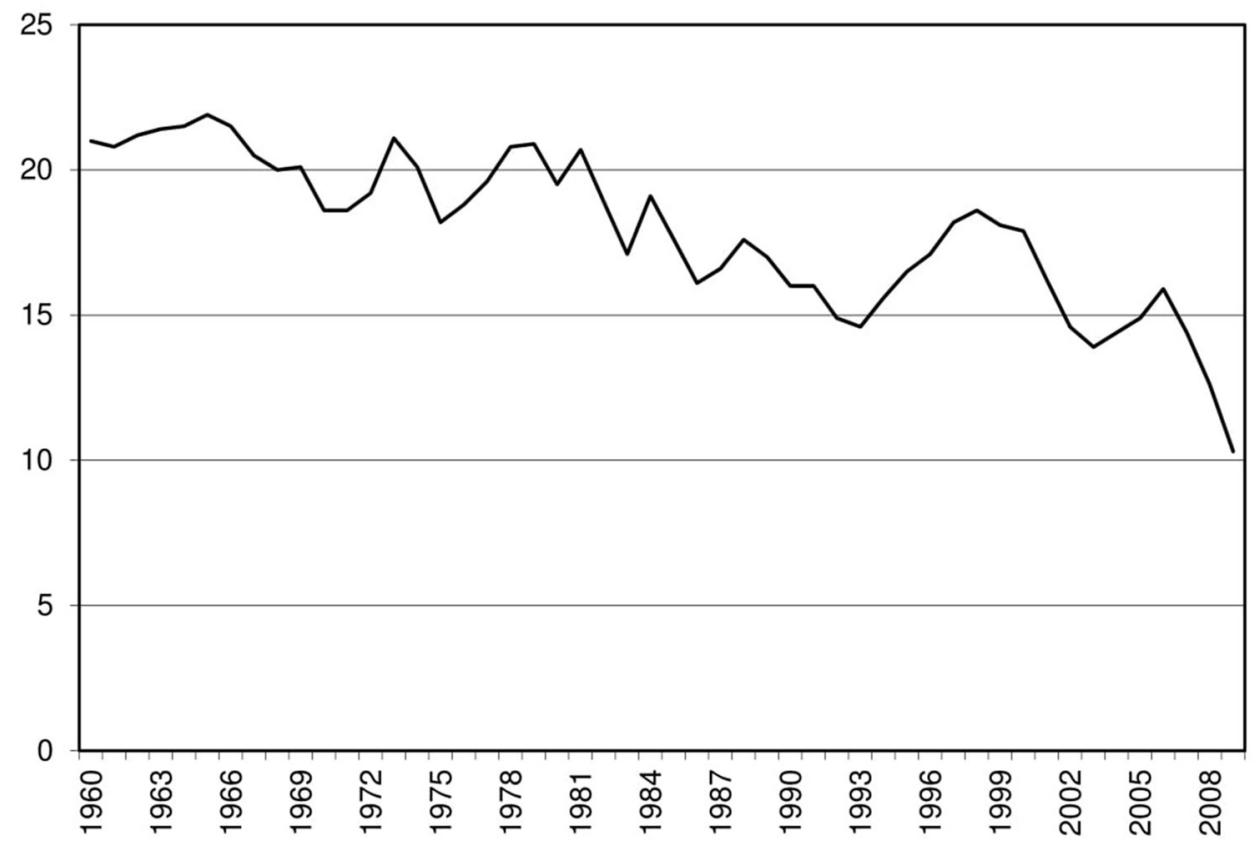

Fonte: elaborado pelo autor, a partir do Council of Economic Advisers (2014).

Gráfico 6 - Taxa de poupança/PIB (Percentual)

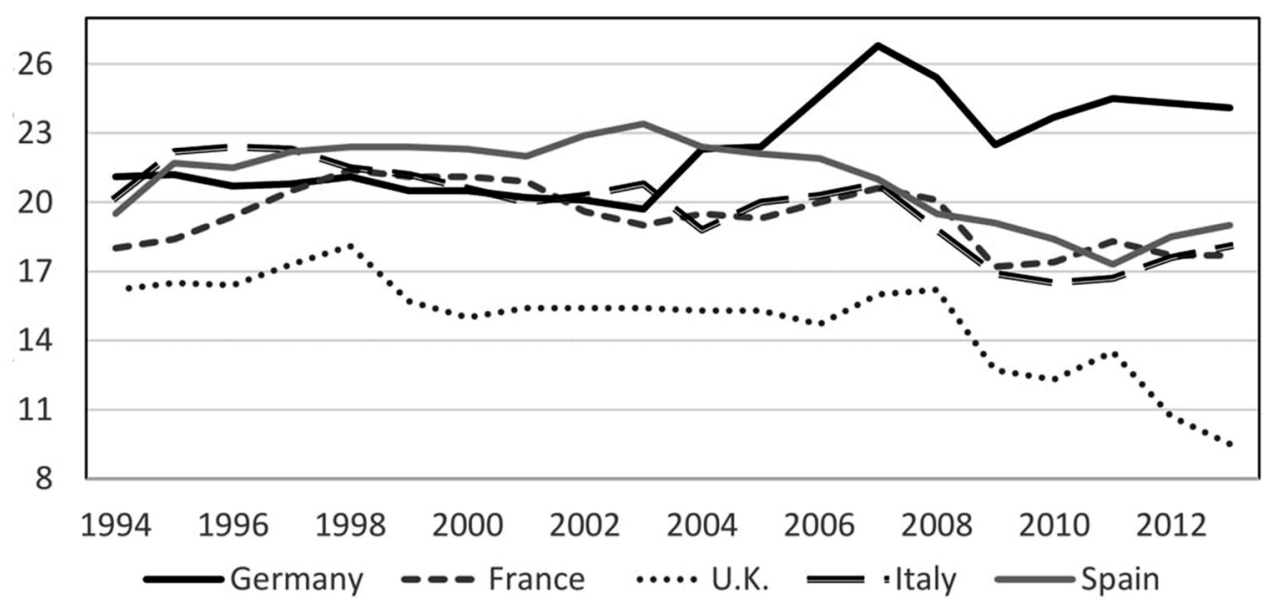

Fonte: elaborado pelo autor, a partir do OECD (2014). 


\section{Gráfico 7 - Lucros das Corporações Financeiras/Lucros totais} das Corporações (Estadunidenses)

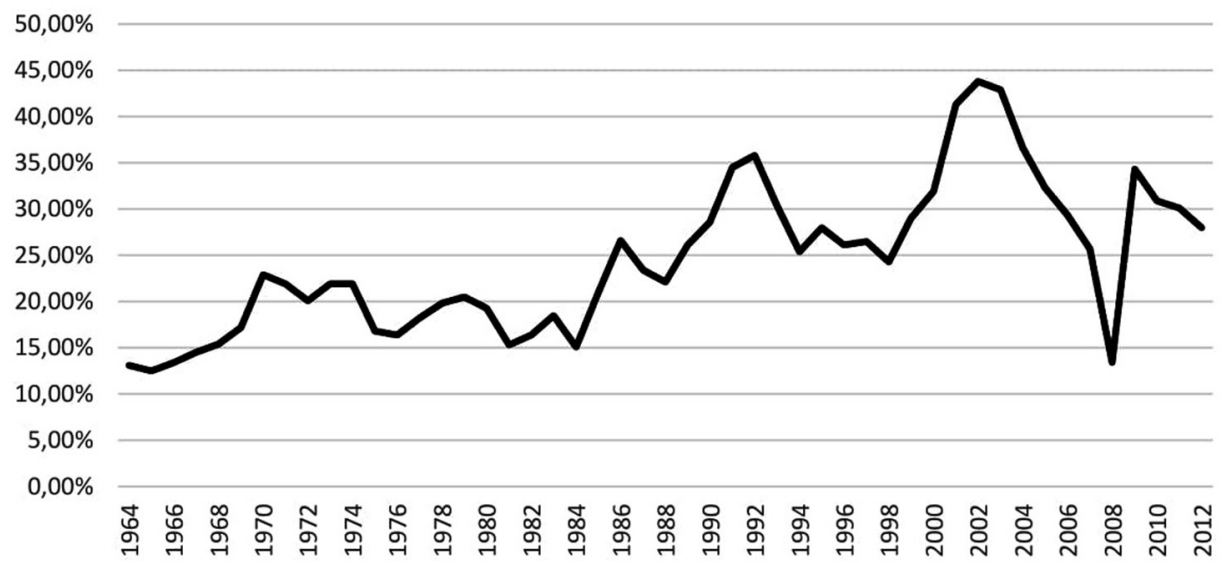

Fonte: elaborado pelo autor, a partir de Council of Economic Advisers (2014).

Gráfico 8 - Estoque de investimento direto externo/PIB

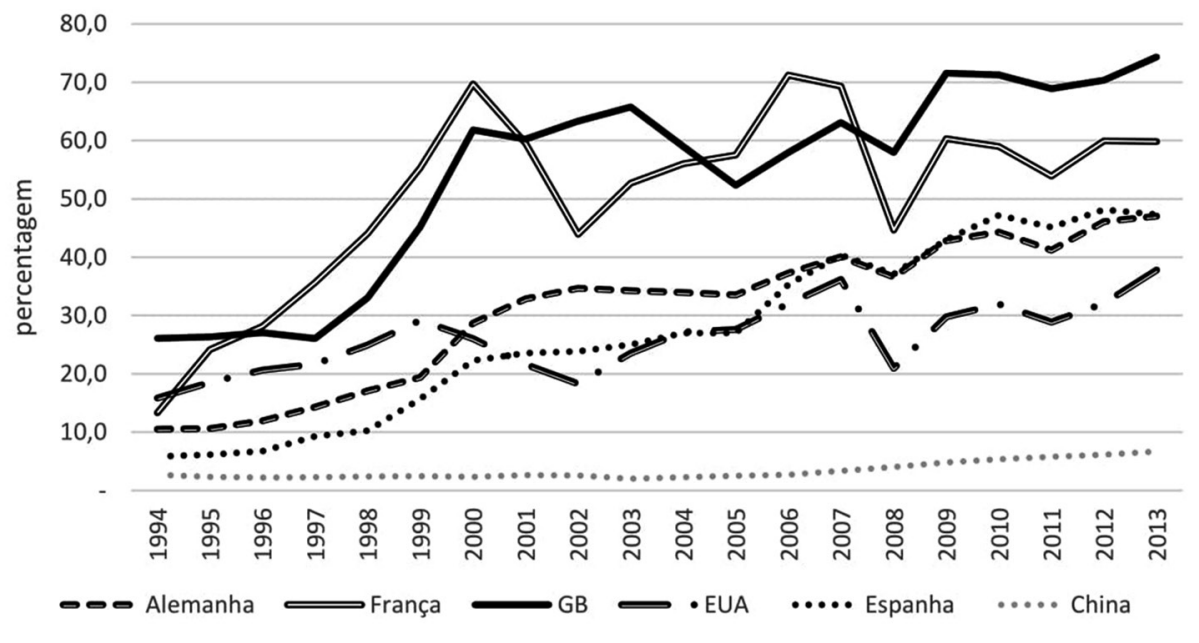

Fonte: UNCTAD. 
estoque externo de capital estrangeiro/PIB entre os principais países europeus, os Estados Unidos e o Japão sinaliza para a relocalização do circuito produtivo do capital das potências atlantistas (Gráfico 8). Tais fatores promovem um lento deslocamento do eixo de poder na divisão internacional do trabalho, manifesta na significativa perda de competividade no comércio internacional de Estados Unidos, Alemanha, França, Reino Unido, Itália e Japão. A perda de competitividade apresenta-se principalmente na redução da participação relativa nas exportações mundiais, ${ }^{11}$ podendo apresentar-se como forte déficit comercial, caso dos Estados Unidos, mas não, necessariamente, caso da Alemanha. ${ }^{12}$

0 saldo comercial da Alemanha saltou de $2,9 \%$ do PIB, em 2000, para alcançar $8 \%$ em 2007. Foi obtido $65 \%$ no interior da Europa, fonte mais dinâmica do saldo que o expandiu no período em $230 \%$ contra $186 \%$ das regiões fora da Europa, cuja principal origem era os Estados Unidos, de onde provinha mais $50 \%$ do superávit comercial extraeuropeu. 0 seu grande determinante foi a contenção salarial que, combinada à alta tecnologia, permitiu à Alemanha impulsionar dramáticos desequilíbrios comerciais, na zona do euro, que provocaram a crise do balanço de pagamentos e da dívida soberana de Grécia, Espanha e Portugal, revertendo a tendência à convergência da renda média europeia que se estabelecia lentamente. As variações positivas de compensação salarial entre a zona do euro e a Alemanha, desde o início de 1990 até 2008, foram muito superiores às de produtividade entre a Alemanha e a zona do euro, que quase se aproximam a 1. No caso da Alemanha, a variação das compensações salariais foi inferior aos índices de inflação para a década de 2000. A Grécia que apresentou, no período, uma variação de produtividade muito superior à alemã, mas também uma expansão salarial bastante acima daquela variação, foi estrangulada em seu processo de convergência. Entre 2001-2013, se a Alemanha passou de 116 a 124 da renda média da União Europeia, a Itália caiu de 119 para 98, a França de 116 para 108, a Espanha de 98 para 95, a Grécia de 87 para 75 e Portugal de 81 para $76 .{ }^{13}$ Essencial para a contenção salarial dos trabalhadores alemães foi a unificação alemã com a destruição de empresas e incorporação de milhões de trabalhadores à Alemanha Ocidental. Utilizando-se do mercado comum europeu em jogo de soma zero, lançando mão de sua vantagem histórica em produtividade, combinando-a com a redução salarial, a Alemanha manteve taxas de investimento bastante superiores à média da União Europeia, fortalecendo-se como espaço de acumulação produtiva, mantendo altos níveis de desemprego, que caem à metade entre 2005-2013, para alcançar 5,5\% e atravessar a crise em tendência inversa à da região. Todavia, nem mesmo se do mercado regional para produzir assimetrias, a Alemanha consegue deter seu processo de declínio, pois a crise europeia e mediterrânea restringe a sua expansão sustentada: o PIB per capita alemão passa de $338 \%$ para $264 \%$ da média da economia mundial entre 1994-2010 (Bolt e Van Zanden, 2014).

Limitada historicamente em sua expansão pelas potências atlantistas que impediram a sua afirmação territorial e marítima no século $X X$, a Alemanha reunificada adota o enfoque neoliberal impulsionado desde os principais centros atlantistas - Estados Unidos e Reino Unido. Ao fazê-lo, articula a financeirização na 
Europa com a criação de um mercado regional regulado por altas taxas de desemprego. Entra, assim, em contradição com sua vocação de longo prazo para afirmar-se como hinterland europeu, capaz de vincular-se a um novo alinhamento geopolítico mundial no qual as potências territoriais e os mercados internos poderão jogar um papel fundamental.

As políticas de superexploração do trabalho elevam fortemente a desigualdade nos países centrais e colocam em xeque o centrismo político, expresso no sistema bipartidário. Nos Estados Unidos, a participação dos 10\% mais ricos no PIB se eleva de $33,4 \%$ a $47,9 \%$ entre 1970-2010; e, na Europa, de 27,6\% a $34,7 \%$ entre 1979-2010, chegando a 36,9\%, caso não se inclua a Suécia. Na Europa, o salto na concentração da renda se dá principalmente no Reino Unido, que evolui de $32,6 \%$, em 1980, para 41,6\%, em 2010, mas, também, é expressiva na Alemanha, passando de 32,6\% para $36,1 \%$ no mesmo intervalo temporal. ${ }^{14} \mathrm{As}$ taxas de desemprego mantêm-se em altos níveis nos Estados Unidos e na Europa, atingindo principalmente à juventude, e os salários reais mantêm-se comprimidos, situando-se, nos Estados Unidos, em níveis inferiores aos de início dos anos $1970 .^{15}$

Na Europa, a crise do bipartidarismo pode ser aferida por dois fatores: pela queda da participação dos dois principais partidos no parlamento europeu e pelo aumento das abstenções. Desde 1999, a participação das duas principais coalizões partidárias no parlamento europeu, de centro-direita e centro-esquerda, caiu de $66 \%$ das cadeiras para $54,8 \%$ em 2014. Também, a taxa de participação do eleitorado vem se reduzindo progressivamente desde 1979 , passando de $62 \%$ para $42,5 \%$ em
2014. Nos Estados Unidos, o sistema bipartidário é bastante mais sólido, mas também sofre desgaste. Pesquisas do Gallup apontam que a parcela da população que considera necessária a criação de um terceiro partido subiu de $40 \%$, em 2003, para $61 \%$ em 2017. ${ }^{16} 0$ mesmo instituto assinala que a confiança no poder executivo não ultrapassou a faixa dos $30 \%$ a partir de 2006 - excetuando o primeiro ano do mandato de Obama, quando atingiu $51 \%$-, alcançando o seu pico de 37\%, em 2012 e 2018, e o seu ponto mais baixo de $26 \%$ em 2006 . Tais índices são muito inferiores aos alcançados entre 1975 e 2005, quando oscilaram entre $72 \%$, durante a Guerra do Golfo, a 38\% em 1994, permanecendo a maior parte do tempo em torno dos 50\%. Queda mais drástica sofre o poder legislativo, cuja confiança cai de $42 \%$, em 1973, para 30\%, em 2004, e $11 \%$, em 2018. A confiança na suprema corte também é afetada: entre 1973-2006 o seu índice de confiança médio foi de $46 \%$, enquanto, entre 2006-2018 este caiu para $32,5 \%{ }^{17}$

A eleição de Obama, um presidente negro, o mais votado da história dos Estados Unidos, motivando, em 2008, a maior participação eleitoral estadunidense desde 1968, reforça a desconfiança com as elites tradicionais anglo-saxãs e o desejo de mudança, o que se acentua com a sua queda de popularidade e incapacidade de restabelecer a confiança no sistema político. A queda contínua de brancos entre os eleitores - que passam de $89 \%$ do total, em 1976, para $71 \%$, em 2016 -, o aumento da participação de latino-americanos, negros e asiáticos, a elevação da desigualdade social e a financeirização pressionam o sistema político para a polarização, reduzindo o espaço estrutural de legitimidade de uma 
política centrista. 0 formato que isto poderá tomar nos Estados Unidos nas próximas décadas é imprevisível: poderá o Partido Democrata inclinar-se à esquerda e o Republicano à direita, atendendo a essa polarização? Ou, no limite, esses partidos poderão ainda cindir-se, criando-se um partido à esquerda do Partido Democrata e outro à direita do Partido Republicano? A eleição de Donald Trump, em forte contradição com a oligarquia do Partido Republicano, e o expressivo desempenho da candidatura de Bernie Sanders são indicativos das profundas tensões que se desenvolvem no sistema bipartidário estadunidense. Não surpreende que a gestão de Trump assuma com muita ênfase as políticas de banimento de imigrantes e se principalmente contra mexicanos, uma vez que o eleitorado branco estadunidense perde o seu poder relativo, sobretudo, para os latinos, e estes têm concentrado o seu voto nos candidatos do Partido Democrata.

\section{A ascensão da China e os Brics: formação de um novo bloco histórico?}

Entre o século XIX e metade do século $X X$, a queda da participação da Ásia no produto mundial foi drástica e se deu em benefício da Europa Ocidental e dos Estados Unidos. Entre 1820-1950, a participação da Ásia caiu de $56,2 \%$ para $15,5 \%$ do PIB mundial, enquanto a da Europa Ocidental e Estados Unidos se elevou de $25,4 \%$ até $56,9 \%$ no mesmo período. Especificamente a China sofreu uma queda de $32,9 \%$ para $4,5 \%$ que foi interrompida em 1950, elevando-se discretamente para
4,6\% em 1973, enquanto a participação da Índia continuou a cair, reduzindo-se de 4,2\% para 3,1\% entre 1950-1973, tomando-se como referência o patamar de $16 \%$, em 1820. A industrialização per capita caiu drasticamente no século XIX, cerca de 6 vezes na Índia, 3 vezes no terceiro mundo e 2 vezes na China, ao passo que se multiplicou por 4 no Reino Unido entre 1830-1900. 0 auge da civilização capitalista ocidental atlantista deu-se entre $1820-1970 .^{18}$

A revolução socialista maoísta interrompeu essa queda, impulsionando a industrialização, a reforma agrária, os investimentos em saúde e educação e um processo de acumulação sem despossessão. Todavia a excessiva centralização administrativa dos processos produtivos pelo Estado, a tentativa de impor grandes escalas de produção sem base tecnológica correlata, a coletivização forçada e a forte transferência de excedentes do campo à indústria geraram má utilização e enormes desperdícios de recursos, limitando o alcance do desenvolvimento chinês. A ofensiva da revolução cultural contra a burocratização do Estado e a monopolização do poder político foram reprimidas, mas encontraram uma resposta no período de Deng Xiao Ping na descentralização administrativa dos processos produtivos, que ampliou a autonomia decisória das populações locais, transferindo poder empresarial do Estado às comunidades, mantendo-se, todavia, a estrutura centralizada do poder político.

Arrighi (2008) ao analisar o processo de ascensão da China na economia mundial em Adam Smith em Pequim, indica como chave para isso a revolução industriosa. Esta, diferentemente da revolução industrial que separava o trabalhador dos meios de 
produção, substituindo-o pelo capital fixo e a maquinaria, investiu na elevação das qualificações e num arranjo tecnológico intensivo em uso do trabalho. A revolução industriosa articulou-se com a longa duração da revolução socialista chinesa que se fundamentou no campesinato e na linha de massas do Partido Comunista e em investimentos sociais, como saúde e educação, mas necessitou da autonomia gerencial para desenvolver-se. 0 estabelecimento do sistema de responsabilidade familiar na agricultura, a criação das towership and villages enterprises (TVEs) - empresas comunais agrícolas e industriais - produziram os estímulos para o uso do trabalho qualificado e o desenvolvimento da atividade gerencial com relativa autonomia. $A$ isto se articularam-se a promoção, pelo Estado, da internalização dos capitais da diáspora chinesa, o desenvolvimento por este de setores estratégicos e de joint ventures com o capital estrangeiro para transferência de tecnologia, mediante participação significativa no controle decisório. 0 PIB chinês subiu de 5,1\% a 7,2\% do PIB mundial entre 1978-1986 e, desde então, a China aprofundou sua vinculação ao mercado internacional, elevando as exportações de $10 \%$ para $39 \%$ do PIB entre 1986-2006.

Durante esse período, a China aproximou-se fortemente dos Estados Unidos, aspirando à condição de G-2. Desvalorizou sua moeda e a fixou ao dólar; aproveitando-se da elevação do valor do iene, criou gigantescos superávits comerciais, financiou uma parte crescente da dívida norte-americana, comprando títulos do FED, e desenvolveu processos de acumulação por despossessão mediante a diminuição radical do emprego público e a expropriação da terra, tornando-a urbana por determinação estatal. 0 coeficiente de Gini elevou-se de 0,30, em 1978, para 0,49, em 2008, e a participação da China no PIB mundial alcançou $17,4 \%$ neste último ano. A economia chinesa assumiu forte perfil industrial, respondendo por $15 \%$ da indústria mundial e $50 \%$ do PIB nacional. ${ }^{19}$ Estruturou-se um setor produtivo baseado num segmento estatal que compreende aproximadamente $30 \%$ do PIB industrial (telecomunicações, petróleo e gás, geração e distribuição de energia, aviação civil, construção naval e defesa); um segmento de joint ventures sob forte presença do Estado mediante participação acionária, presença nos conselhos decisórios, controle do crédito, encadeamentos tecnológicos (maquinarias, automóveis, tecnologias da informação, $P \& D$, química, metais básicos, aço e exploração geológica); e outro segmento de pequenas e médias empresas em que se destacam as TVEs, que foram quase totalmente privatizadas, resultando em casos de insider privatization, em que os gerentes se tornaram seus proprietários, a partir de estímulos governamentais. ${ }^{20}$

Todavia, a crise mundial de 2008 colocou em xeque esse modelo e sinalizou seus importantes limites estruturais: a vinculação prioritária ao mercado norte-americano tornou a China cada vez mais vulnerável às suas instabilidades, arriscando-se a importar suas crises; a elevação da desigualdade pressionou no sentido da busca permanente de níveis elevados de crescimento econômico para reduzir as tensões sociais que vão se acumulando; o alto grau de concentração industrial elevou a dependência de commodities aumentando a vulnerabilidade externa e a exposição ao seu ciclo de preços, ao tempo que impulsionou os desequilíbrios 
macroeconômicos internacionais; e o alto nível de poluição provocado pela concentração industrial e altas taxas de crescimento degradou as condições de vida e violou o desenvolvimento sustentável. A ameaça de internalização da crise mundial de 2008, com epicentro no eixo atlantista, fez o governo chinês iniciar uma revisão desse modelo de expansão, priorizando o mercado interno. Para isso, estabeleceu um pacote fiscal anticrise equivalente a $9 \%$ do PIB, que impulsionou gastos públicos orientados a infraestrutura, inovação, habitação, apoio à agricultura, saúde e seguridade social; valorizou o yuan para conter as exportações; elaborou $012^{\circ}$ plano quinquenal que se propõe a impulsionar a transição de uma economia industrial baseada no crescimento quantitativo para outra de crescimento qualitativo, fundada na construção de uma economia de serviços vinculada à alta tecnologia industrial, à ciência, à promoção do bem-estar, à diminuição da concentração de renda, à sustentabilidade e redução do uso de combustíveis fósseis; e formalizou o estabelecimento do Brics, que criou outro foco de expansão para a política externa chinesa que se vincula à construção de uma força internacional centrada na aliança entre países com forte vocação continental e com grande projeção para o Sul, com expectativas e potencialidade de afetar a médio ou a longo prazo o alinhamento geopolítico internacional e suas estruturas de poder.

A Carta de Fortaleza, resultado da VI Cúpula dos Brics, afirmou que esses países estão empenhados na construção de um marco intergovernamental inclusivo, transparente e participativo, com uma agenda de desenvolvimento universal e voltada para a erradicação da pobreza. Estabeleceu a criação de um novo banco de desenvolvimento, dedicado a ultrapassar os problemas de financiamento que os países emergentes e em desenvolvimento enfrentam para resolver questões de infraestrutura. Respaldou o acordo de comércio e investimento em moedas locais, formalizado pelos Brics, em 2012, e propôs swaps de divisas como mecanismo para limitar o uso do dólar. Afirmou a importância das empresas estatais, da cooperação e do intercâmbio internacional entre elas, bem como das pequenas e médias empresas, para a promoção do desenvolvimento. Assumiu particular preocupação com 0 desenvolvimento de infraestrutura e da indústria na África. Estabeleceu, ainda, um fundo de estabilização contra ataques especulativos internacionais e fez fortes críticas ao Banco Mundial e ao FMI por não democratizarem suas estruturas decisórias e seus sistemas de cotas, considerando a meta de erradicação da pobreza extrema inalcançável nesses termos. Propôs a reforma do Conselho de Segurança para que Brasil, Índia e África do Sul pudessem jogar um papel mais decisivo nas Nações Unidas. Afirmou que a segurança é um bem coletivo e que nenhum Estado deve fortalecer sua segurança em detrimento dos demais. A Carta assumiu posições anti-imperialistas, defendendo uma solução não militar para a crise política na Síria, o estabelecimento de uma zona livre de armas nucleares e de destruição em massa no Oriente Médio e a soberania de um Estado Palestino com base nas linhas de 4 de junho de 1967, convivendo pacificamente com Israel. Assumiu a preocupação com as crises humanitárias e políticas na África, no Oriente Médio e no Afeganistão, propondo a mediação das Nações Unidas e de mecanismos negociados e consensuais de solução. 
Abre-se, portanto, um espaço de acumulação de poder capaz de retomar o espírito de Bandung, ancorado em bases materiais muito mais poderosas, impulsionado pela ascensão chinesa na primeira década do século XXI, como já mencionava Arrighi (2008 e 2010) ao analisar a emergência dos países do Sul. ${ }^{21}$ Os Brics apresentam uma agenda que: a) propõe um giro dos investimentos financeiros para os produtivos, o que, no limite, pode ameaçar os lucros monopólicos ao pressionar para baixo os preços das mercadorias; b) constrói marcos intergovernamentais que envolvem diretamente $40 \%$ da humanidade e que podem ampliar-se para o Sul, criando possibilidades muito menos assimétricas de relação entre os poderes econômicos e sociais que as impulsionadas globalmente pelas potências marítimas; c) fortalece um padrão de desenvolvimento fortemente apoiado em empresas estatais e pequenas e médias empresas, de caráter inclusivo e universalista; d) questiona a hegemonia atlantista na economia mundial materializada no controle do sistema de Bretton Woods e ONU, no monopólio financeiro e tecnológico de suas burguesias e no imperialismo; e) impulsiona um padrão de política externa anti-imperialista, baseado nos princípios da soberania, autodeterminação dos povos, solução negociada de conflitos.

Entre os fatores que impulsionam os Brics, como embrião de um novo bloco histórico territorialista capaz de disputar o poder no sistema mundial, num período de caos sistêmico, estão: a posição similar de sua população em termos de renda per capita, próxima da média da economia mundial; o seu amplo potencial de mercado interno e regional como fator de expansão; o fato de terem sido alvos da expansão imperialista das potências atlantistas, o que limitou sua vocação regional; a forte presença do nacionalismo e das esquerdas como fator interno de legitimação popular desses Estados e no conjunto dos países periféricos e semiperiféricos; e o interesse dessas forças nacionalistas e de esquerda em quebrar os monopólios tecnológicos, financeiros e comerciais mundiais. Tais elementos respondem pelo alto grau de convergência histórica desses países nas votações na Assembleia das Nações Unidas; cerca de $80 \%$ delas, entre 1974-2008, em particular em temas como multilateralismo, defesa da soberania nacional, direitos de autodeterminação e democratização dos poderes internacionais. ${ }^{22}$

Todavia o que impulsiona o bloco territorialista são as lutas internas dentro de cada Estado. São estas que poderão fazê-lo cumprir ou não a sua vocação estratégica no sistema mundial. Se, na transição para a hegemonia britânica, as lutas intraestatais foram condicionadas e precedidas pelas lutas interestatais, na transição para a hegemonia estadunidense, articularam-se a estas, desempenhando a polarização fascismo ou socialismo um papel importante nesse processo. Numa futura transição para outro sistema de poder, as lutas intraestatais tendem a ser protagônicas e condicionantes em relação às lutas intraestatais, sendo decisivas para suas formas e desenvolvimento. ${ }^{23} \mathrm{~A}$ explicação para tal mudança está no papel crescente que desempenham os trabalhadores e os movimentos sociais na longa duração do desenvolvimento capitalista, pressionando o Estado e o sistema político. Portanto, será a luta de classes no interior desses Estados e das potências marítimas que darão o formato da transição e da bifurcação que 
precede ao novo sistema de poder. As crises sinalizadoras - indicadas por Arrighi como típicas do esgotamento da fase de expansão - são os momentos em que se configuram os fundamentos de um futuro bloco de poder a disputar a transição sistêmica. Na crise sinalizadora britânica se evidenciou a emergência dos protecionismos (guerra da secessão, unificação alemã e revolução Meiji) que disputariam posteriormente a sucessão britânica, panorama ao qual se acresceria o peso decisivo da revolução soviética; na crise sinalizadora estadunidense se evidenciou, a partir da derrota norte-americana no Vietnã, a aliança entre povos do sul e os movimentos de massa no principal centro atlantista para derrotar o politicamente projeto de dominação militar imperialista e afirmar uma revolução social na periferia. Tal precedente histórico indica que o territorialismo poderá se afirmar como um bloco histórico que articule as lutas dos trabalhadores das periferias, semiperiferias e centros contra a produção de riqueza oligárquica, assimetrias e guerras no sistema mundial. Seu epicentro deverá estar na periferias e semiperiferias, em particular nas potências emergentes que as articulem, mas deverá se desdobrar aos grandes centros europeus e atlantistas, alcançando as massas de trabalhadores superexplorados, os migrantes e os setores médios que sofrem com o avanço da desigualdade, a qual deverá se aprofundar nesta década, caso se esgote efetivamente, como postulamos, a fase expansiva do ciclo de Kondratiev. Ao priorizar os mercados internos, a erradicação da pobreza, os regionalismos, suas alianças e a democratização do poder mundial, o territorialismo constitui-se como uma força com alto potencial de contradição com a dinâmica do lucro extraordinário na economia mundial que estrutura a civilização capitalista.

Entretanto, é preciso ter cuidado e evitar os determinismos que não exprimem a complexidade dos períodos caóticos de bifurcações históricas para os quais nos aproximamos: caso prevaleçam os interesses competitivos e oligárquicos de grupos e frações de classe que dirigem os Estados mais dinâmicos dos Brics, como China e Rússia; e caso prevaleçam as burguesias dependentes e sua presença na estrutura estatal de Brasil, África do Sul e Índia; dificilmente este bloco histórico poderá se formar. Nesse contexto, a ascensão da China representará uma reacomodação num sistema de produção de riqueza oligárquica, que funciona como um jogo de soma zero, regulando ascensões e descensos, cuja resultante lógica, como compensação, poderá ser a queda de países semiperiféricos e periféricos para as profundezas da periferia.

O golpe de Estado no Brasil, o cerco político e econômico aos governos nacionais- populares da região impulsionados pela ofensiva neoconservadora na América Latina e sua articulação ao grande capital estadunidense fragilizam a alternativa geopolítica global lançada pelos Brics, a partir de 2009, quando realizaram sua primeira conferência internacional, mas não configuram uma vitória definitiva. A ofensiva neoconservadora na América Latina aprofunda a crise do capitalismo dependente da globalização neoliberal e se inscreve em um período mais amplo de confrontações que configuram o caos sistêmico que deverá predominar nas próximas décadas, quando as lutas sociais deverão se agudizar e assumir forte dimensão internacionalista, com os cenários nacionais em disputa, 
alcançando alto grau de interpenetração e influência recíproca.

\section{Conclusão}

Neste artigo, buscamos apontar as especificidades da conjuntura contemporânea a partir da análise das tendências de longa duração da economia mundial. Destacamos a crise de hegemonia do eixo atlantista da economia mundial liderado pelos Estados Unidos, que se estende ao centro e ao norte da Europa Ocidental. Essa crise se aprofunda durante a fase expansiva do ciclo de Kondratiev vigente, iniciada em 1994 e que deverá se esgotar nos próximos anos. Consideramos que a fase expansiva do atual ciclo de Kondratiev tem sido chave para amortecer as contradições impulsionadas pela revolução científico-técnica e pela crise de hegemonia dos Estados Unidos. 0 seu esgotamento deverá abrir um período de caos sistêmico e de crise da civilização capitalista, e sua principal expressão, o liberalismo político global, que impulsionará as lutas de classes em âmbito nacional e transnacional.
Esse período de caos sistêmico que se avizinha lança imensas incertezas e projetos políticos em confronto. Entre eles, podemos destacar o da restruturação do velho eixo atlantista a partir do fortalecimento do imperialismo político para controlar as pressões competitivas oriundas da globalização e as da organização da classe trabalhadora; e o da projeção da China como um dos pilares de uma nova ordem mundial que se dirige aos hinterlands e ao Sul global para a formação de um novo eixo geopolítico, capaz de refundar o sistema mundial na direção de uma civilização planetária, comprometida com a pluralidade, maior centralização política e a imposição de fortes controles estatais sobre a acumulação de capitais. De grande importância serão a organização e as lutas da classe trabalhadora para que esses controles se exerçam para impulsionar os serviços públicos em saúde, educação, lazer, infraestrutura e preservação dos ecossistemas. Esses grandes alinhamentos tendem a definir limites e as possibilidades que o Brasil e a América Latina encontrarão nos próximos anos para desenhar seus caminhos. A soberania e a democracia popular e participativa tornam-se cruciais para os escolhermos.

\section{[I] https://orcid.org/0000-0003-1333-6737}

Universidade Federal do Rio de Janeiro, Instituto de Relações Internacionais e Defesa, Programa de Pós-Graduação em Economia Política Internacional. Rio de Janeiro, RJBrasil.

cadu.m@uol.com.br 


\section{Notas}

(1) A série estatística pode visualizada a partir do seguinte endereço eletrônico: http://www.ggdc. net/maddison/maddison-project/home.htm. Acesso em: 10 jan 2018.

(2) Segundo o OECD Economic Outlook 2014, os Estados Unidos representavam aproximadamente $12 \%$ das importações mundiais e $9 \%$ destas exportações em 2012 ao passo que, em 1998, representavam $16,3 \%$ e $13,8 \%$, respectivamente. Segundo a serie estabelecida por Angus Maddison, em 2008, os Estados Unidos representavam 18,6\% do PIB mundial e, em 1994, 21,5\%. A crise de 2008-10 baixou ainda mais o patamar do PIB estadunidense, aproximando-o de $17 \%$ em 2010.

(3) Cálculos do autor a partir do World Economic Outlook, publicado em abril de 2018 e dos dados do Banco Mundial sobre crescimento da população mundial. A série do FMI apresenta distinções metodológicas em relação à apresentada pelos seguidores da obra de Maddison em 2013, devendo ser usada apenas como aproximação a esta.

(4) Veja-se http://www.imf.org/external/datamapper/PPPSH@WEO/OEMDC/ADVEC/WEOWORLD. Acesso em: 10 jan 2018.

(5) Temos mostrado em um conjunto de trabalhos os efeitos da mundialização da revolução cientifica técnica sobre o processo de trabalho, a formação do valor e os processos de acumulação de capital. Ao tornar o valor da força de trabalho, em particular, a sua qualificação, o elemento central das forças produtivas, a revolução científico-técnica impulsiona a redução da diferença entre o valor do trabalho e o valor da força de trabalho pressionando negativamente a taxa de mais-valia. Este contexto qualificamos de crise civilizatória e se aproxima ao de era revolucionaria descrito por Marx no Prefácio à contribuição à crítica da economia política, quando uma nova estrutura de forças produtivas entra em contradição com as relações de produção e suas formas de propriedade. Para apropriar-se da revolução cientifico-técnica, o capital necessita estabelecer políticas de superexploração do trabalho, reduzindo os preços da força de trabalho por debaixo de seu valor, o que o leva, nos países centrais, a romper o pacto keynesiano com os trabalhadores e a deslocar parte do seu circuito de valorização para a acumulação financeira ou para outras regiões do mundo, onde a relação entre o valor do trabalho e o valor da força de trabalho lhe seja mais favorável.

(6) Cálculo do autor a partir da série estabelecida pelos discípulos de Angus Maddison em 2013, atualizando sua metodologia, e que pode ser acessada em https://www.rug.nl/ggdc/ historicaldevelopment/maddison/releases/maddison-project-database-2013. Acesso em: 10 jan 2018.

(7) Ver Arrighi e Silver (2001).

(8) Desta forma a China transfere para si o saldo comercial com os Estados Unidos apropriando-se de grande parte do mercado interno estadunidense, elevando os déficits em conta corrente e endividamento externo deste país via internacionalização de sua dívida pública, na qual os chineses terão participação crescente.

(9) Cálculo do autor a partir da série estabelecida por Angus Maddison e seus discípulos: http://www. ggdc.net/maddison/maddison-project/home.htm. Acesso em: 10 jan 2018. 
(10) Conferir em http://www.federalreserve.gov/econresdata/releases/mortoutstand/current.htm. Acesso em: 10 jan 2018.

(11) Entre 2000-2017 a participação agregada de Estados Unidos, Alemanha, Itália, França, Grã-Bretanha, e Japão nas exportações mundiais caiu de $42,6 \%$ para $31,4 \%$. Ver The Economic Outlook, 2018.1, publicado pela OCDE.

(12) Os Estados Unidos após forte escalada do déficit comercial que atinge seu pico em 2008, o reduzem significativamente em função da desvalorização do dólar, da diminuição do déficit da conta-petróleo e da apreciação do yuan. A diminuição do déficit da conta-petróleo vincula-se principalmente à substituição da importação de petróleo pela produção local e pelo gás de xisto - com fortes impactos ecológicos. Todavia é cada vez menor o espaço para o impacto desta redução no resultado global da balança comercial, uma vez que o déficit da conta-petróleo cai de $47 \%$ para $7,6 \%$ do déficit total entre $2008-2017$, e aquela continua a ser pressionada pela competitividade de outras regiões do mundo, principalmente a chinesa. Ver: https://www.census.gov/foreign-trade/statistics/historical/petro.pdf. Acesso em: 10 jan 2018.

(13) Ver http://epp.eurostat.ec.europa.eu/portal/page/portal/eurostat/home/. Acesso em: 10 jan 2018.

(14) Ver Council of Economic Advisers (2014) e Piketty (2014).

(15) Nos Estados Unidos, as taxas de desemprego aparentemente mais baixas vinculam-se tanto à maior capacidade de sustentar no longo prazo a sobrevalorização da moeda nacional quanto à invisibilização do trabalho precarizado que cresceu. Embora as taxas de desemprego aberto tenham se reduzido, ainda que lentamente, após a crise de 2008-2010, os trabalhadores de tempo completo representam 82\% do total em 2017, quando eram 86,5\% deste em 1968. Veja-se a série de longo prazo em https://fred.stlouisfed.org/graph/?category_id=\&graph_ $\mathrm{id}=308940$. Acesso em: 10 jan 2018.

(16) Veja-se em https://news.gallup.com/poll/219953/perceived-need-third-major-party-remainshigh.asp. Acesso em: 10 jan 2018.

(17) Veja-se em https://news.gallup.com/poll/1597/confidence-institutions.aspx. Acesso em: 10 jan 2018.

(18) Ver Kennedy (1987) e Maddison (2001).

(19) Veja-se OECD (2013).

(20) Veja-se Martins (2013).

(21) Ver Arrighi (2008 e 2010).

(22) Veja-se Ferdinand (2014).

(23) Ver Arrighi (1994), Arrighi e Silver (2001), Martins (2011b). 


\section{Referências}

ARRIGHI, G. (1994). O longo século XX de Giovanni. São Paulo, Editora Unesp.

(1997). A ilusão do desenvolvimento. Petrópolis, Vozes.

(2008). Adam Smith em Pequim. São Paulo, Boitempo.

(2010). Zhang Lu Beyond the Washington consensus: a new Bandung? Disponível em: http:// krieger.jhu.edu/arrighi/wp-content/uploads/sites/29/2012/08/Arrighi_and_Zhang_NewBandung_3-16-09_version.pdf. Acesso em: 10 jan 2018.

ARRIGHI, G. e SILVER, B. (2001). Caos e governabilidade no moderno sistema mundial. Rio de Janeiro, Contraponto (edição original de 1999, por Minnesotta Press).

BOLT, J. e VAN ZANDEN, J. L. (2014). The Maddison Project: collaborative research on historical national accounts. Maddison Project Datyabase, version 2013. The Economic History Review, v. 67, n. 3, pp. 627-651, working paper.

CASSIOLATO, J. E. e VITORINO, V. (2011). BRICS and Development Alternatives. Londres, Anthen Press.

COUNCIL OF ECONOMIC ADVISERS (2014). Economic Report of The President. Washington, United States Government Printing Office.

FERDINAND, P. (2014). Rising powers at the UN: an analysis of the voting behaviour of the BRICS in the General Assembly. Journal Third World Quarterly, v. 35, n. 3, pp. 376-391. Disponível em: https:// www.tandfonline.com/doi/abs/10.1080/01436597.2014.893483. Acesso em: 10 jan 2018.

JIADONG, C. et al. (2010). The trend of the Gini coeficient em China. Manchester, BWPI Working Paper Center.

KENNEDY, P. (1987). Ascensão e queda das grandes potências.

KUNG, J. e LIN, Y. (2007). The decline of towership and village enterprise in China`s economic transition. World Development, v. 35, n. 4, Elsevier.

MARTINS, C. E. (2011a). “A América Latina e a conjuntura mundial: conjuntura, desenvolvimento e prospectiva". In: VIANA, A.; BARROS, P.e CALIXTRE, A. (orgs.). Governança global e integração na América do Sul. Brasília, Ipea.

(2011b). Globalização, dependência e neoliberalismo na América Latina. São Paulo, Boitempo.

(2013). “A Geopolítica Mundial e a economia política no século XXI: hegemonia, BRICS e América Latina". In: FLORES, C. S. e MARTINS, C. E. Nuevos escenarios para la integracion en América Latina. Santiago de Chile, Editorial Arcis.

MADDISON, A. (2001). The World Economy. Paris, OECD.

McNALLY, C. (org.) (2008). China's emergente political economy: capitalism in the dragon's lair. Nova York, Routledge.

MORAES, I. N. (2011). Desenvolvimento econômico, distribuição de renda e pobreza na China Contemporânea. Tese de Doutorado. Rio de Janeiro, Universidade Federal do Rio de Janeiro.

NATIONAL BUREAU OF STATISTICS OF POPULAR REPUBLIC OF CHINA (2010). China Statistical Yearbook. China Statistics Press. Oct 2010, 1032 (China Statistical Yearbook Series). 
OECD (1998). Historical Statistics: 1960-1997. Paris, OECD.

(2001). Historical Statistics: 1970-2000. Paris, OECD.

(2010). OECD Economic Surveys: China. Paris, OECD.

(2013). OECD Economic Surveys: China. Paris, OECD.

(2014). OECD Economic Outlook, v. 2014, n. 1. Disponível em: https://www.oecd-ilibrary.org/ economics/oecd-economic-outlook-volume-2014-issue-1_eco_outlook-v2014-1-en. Acesso em: 10 jan 2018.

PIKETTY, T. (2014). Capital in the Twenty-First Century. Cambridge, Harvard University Press.

UNCTAD - UNITED NATIONS CONFERENCE ON TRADE AND DEVELOPMENT. Disponível em: https:// unctad.org/en/Pages/statistics.aspx. Acesso em: 10 jan 2018.

YONGQIANG, L. (2009). An overview of township and village enterprises in China during 1949-2009. Proceedings of the 2nd International Conference on Corporate Governance. Disponível em: http://www.une.edu.au/business-school/research/corp-gov-conf/papers/li-tves.pdf. Acesso em: 10 jan 2018.

Texto recebido em $30 / j u l / 2018$

Texto aprovado em 12/set/2018 